\title{
NILAI-NILAI PENDIDIKAN ISLAM DALAM AL-QUR'AN SURAT ALI IMRAN AYAT 37
}

\author{
Chumaidah Syc \\ Prodi Pendidikan Agama Islam (PAI), STIT al Urwatul Wutsqo Jombang \\ Yuni Astutik \\ Prodi Pendidikan Agama Islam (PAI), STIT al Urwatul Wutsqo Jombang \\ e-mail: astutiky19@yahoo.com
}

\begin{abstract}
Abstract: Islamic education is an important part in the world of education. Because humans not only need knowledge, but also need spiritual power of religion to form a whole human being (insan kamil) in accordance with Islamic norms. This study discusses "Islamic Education Values Contained in the Qur'an, Surat Ali Imran Verse 37". Research method in this study used literature review research. In this study, researchers found that the concepts of Islamic educational values are a collection of life principles, teachings about how humans should carry out their lives in the world, one principle with each other related to forming a unified whole that is inseparable inherent in Islamic education which is used as a basis for humans to achieve the goals of human life that is to be a human being and serve God Almighty. There are two types of Islamic educational values, namely Ilahiyah values and Insaniyah values. The results of this study the researchers concluded that the values of Islamic education contained in al-Qur'an Surah Ali Imran verse 37: 1). Ilahiyah Values, such as, Faith, Islam, piety, sincerity, trust, gratitude and patience. 2). Insaniyah values include al-ukhuwah, tawadhu ', al-wafa, husnudzan., Al-amanah, and al-munfiqun.
\end{abstract}

Keywords: Values, Islamic Education, Study of Al-Qur'an Surah Ali Imran Verse 37

\section{A. Pendahuluan}

Pendidikan adalah segala kegiatan yang berlangsung sepanjang zaman dalam situasi kegiatan kehidupan. Selain itu pendidikan adalah sistem pembaharuan menuju kedewasaan, pencerdasan dan kematangan diri. Dewasa dalam hal perkembangan badan, cerdas dalam hal perkembangan jiwa dan matang dalam hal perilaku. Perkembangan ilmu pengetahuan dan teknologi 
sudah semakin pesat. Arus globalisasi sudah semakin hebat. Salah satu cara yang ditempuh untuk menanggulanginya adalah melalui mutu pendidikan. ${ }^{1}$

Pendidikan juga dapat diartikan sebagai upaya manusia dewasa dalam membimbing kepada yang belum dewasa untuk mencapai kedewasaan. Jadi dalam hal pendidikan pada hakikatya suatu kegiatan yang secara sadar dan disengaja, serta penuh tanggung jawab yang dilakukan oleh orang dewasa kepada anak sehingga timbul interaksi dari keduanya agar anak tersebut mencapai kedewaan yang dicita-citakan dan berlangsung terus menerus. ${ }^{2}$

Pendidikan jika dikaitkan dengan keberadaan dan hakikat kehidupan manusia, yakni untuk membentuk kepribadian manusia, mengembangkan manusia sebagai makhluk individu, makhluk sosial, makhluk susila, dan makhluk religius. ${ }^{3}$ Pendidikan merupakan kebutuhan pokok bagi manusia, karena manusia disaat dilahirkan tidak mengetahui sesuatu apapun ${ }^{4}$ .Dalam pendidikan ada pembelajaran, pembelajaran pada hakekatnya Sebuah proses interaksi antara peserta didik dengan lingkungannya, dan harus menekankan pada praktek. sehingga terjadi perubahan perilaku ke arah yang lebih baik ${ }^{5}$. Syariat Islam sangat menganjurkan bagi muslim dan muslimat untuk meraih pendidikan sampai akhir hayat. Untuk itu dalam hal pendidikan tidak hanya laki-laki saja yang berhak mendapatkan pendidikan tetapi perempuan juga berhak mendapatkan pendidikan. Sebagaimana sabda Rasulullah SAW. tentang kewajiban menuntut ilmu, yaitu sebagai berikut:

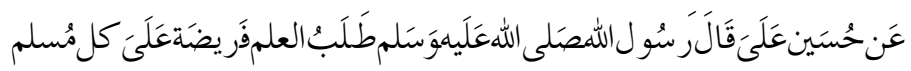

\footnotetext{
${ }^{1}$ Suparlan Suhartono, Filsafat Pendidikan (Yogyakarta: Ar-Ruzz, 2006), 79.

${ }^{2}$ Ibid, 70,71.

${ }^{3}$ Siti Farikhah, Manajemen Lembaga Pendidikan (Yogyakarta: Aswaja Pressindo, 2011), 237.

${ }^{4}$ Ali Mustofa, Pendidikan Keagamaan Untuk Membentuk Kerukunan Antar Umat Beragama Di Medowo Kandangan Kediri, Nazhruna: Jurnal Pendidikan Islam Vol. 3 No 1 2020. Hal. 17. ISSN: 2614-8013. DOI: https://doi.org/10.31538/nzh.v3i1.399

${ }^{5}$ Nurul Indana, Kepimpinan Kepala Sekolah dalam Pengembangan Pembelajaran PAI di SMP Islam Terpadu Misykat Al Anwar Kwaron Diwek Jombang. Jurnal Al-Idaroh Vol.3 No.2 September 2019.
} 
Artinya: "Husain bin Ali meriwayatkan bahwa Rasululloh SAW. bersabda, " Menuntut ilmu wajib bagi setiap orang Islam.' (HR. Al-Baihaqi, Ath-Thabrani, Abu Ya'la, Al-Qudha'i, dan Abu Nu'aim Al-Ashbahani). "6

Berdasarkan hadis diatas, perintah menuntut ilmu pengetahuan atau belajar adalah untuk seluruh umat Islam berarti tidak hanya kepada kaum laki-laki, tetapi juga kepada kaum perempuan. Pendidikan perempuan merupakan suatu hal yang sangat urgen untuk diperhatikan, mengingat perempuan adalah calon ibu yang akan berperan penting mewarnai kehidupan anak-anaknya. Apabila yang dididik anak laki-laki (calon bapak), maka hasilnya tidak akan melampaui pribadi satu orang, tetapi bila yang dididik anak perempuan (calon ibu) maka ia berarti mendidik satu keluarga. ${ }^{7}$

Anak-anak perempuan haruslah mendapat perhatian pendidikannya untuk menumbuhkan kepribadian dan berbagai potensi yang mereka miliki yakni dengan diajarkannya nilai-nilai pendidikan Islam terutama yang berkaitan dengan pendidikan akhlak. Pribadi Rasulullah SAW. adalah contoh yang paling tepat untuk dijadikan teladan dalam membentuk pribadi yang akhlakul karimah. Seorang muslim tidak sempurna agamanya jika akhlaknya tida baik, maka pendidikan akhlak dapat dikatakan sebagai jiwa pendidikan Islam. Jadi jika ingin membangun masyarakat mulia dan terhormat maka harus diperhatikan secara penuh pendidikan dan pembinaan anak perempuan dengan menentukan program yang sesuai dengan jiwa, memperhatikan naluri dan insting kewanitaannya. ${ }^{8}$

Islam sangat memperhatikan pendidikan bagi anak perempuan. Anak perempuan yang sekarang ini merupakan pencipta dan pembentuk masyarakat masa depan, oleh karena itu harus diperhatikan pendidikannya seawal mungkin. Bagi seorang pendidik juga dijanjikan dalam hadits bahwa siapa yang mendidik anak perempuannya dengan baik maka ia akan terbentengi dari siksa neraka dan dijanjikan masuk surga.

\footnotetext{
${ }^{6}$ Bukhari Muslim, Hadis Tarbawi (Jakarta: Amzah, 2006), 7.

${ }^{7}$ Abuddin Nata, Metodologi Studi Islam (Jakarta: Raja Grafindo Persada, 2012), 207.

${ }^{8}$ Ibid, 190.
} 
Para pendidik dengan mengarahkan dan membimbing anak-anak maka akan memberikan kesehatan ilmu, kekuatan kepada anak-anak. Mereka akan terlindungi dari kenakalan dan penyimpangan. Selanjutnya, waktuwaktu luang mereka akan terisi dengan perkara yang bermanfaat bagi dunia, agama, akhirat mereka. Sehingga mereka telah disiapkan menjadi generasi Islam. ${ }^{9}$ Maka pendidikan Islam secara sederhana adalah pendidikan yang berdasarkan ajaran Islam yakni upaya membimbing, mengarahkan, dan membina peserta didik yang dilakukan secara sadar dan terencana agar terbina suatu kepribadian yang utama sesuai dengan nilai-nilai ajaran Islam. ${ }^{10}$ Di dalam al-Qur'an terdapat banyak ajaran yang berisi tentang nilai-nilai pendidikan Islam dan salah satunya adalah firman Allah dalam al-Qur'an surat Ali Imran ayat 37. Ayat itu menunjukkan banyak sekali nilai-nilai pendidikan yang terkandung dalam ayat al-Qur'an tersebut. Sementara itu pendidikan Islam adalah segala usaha untuk memelihara dan mengembangkan fitroh manusia serta sumber daya manusia yang ada padanya menuju terbentuknya manusia seutuhnya (insan kamil) sesuai dengan norma Islam. ${ }^{11}$ Pandangan tokoh pendidikan Islam Qasim Amin berkaitan dengan pendidikan perempuan, berpandangan bahwa pendidikan dan pengajaran perempuan adalah sesuatu yang perlu. Dengan bekal pendidikan, perempuan dapat terbebaskan diri dari segala bentuk mitos atau tahayul. Lebih dari itu pendidikan juga merupakan modal bagi manusia untuk mencapai kebahagiaan hidup secara material maupun non material. ${ }^{12}$

Manusia yang berpredikat muslim, benar-benar menjadi penganut agama yag baik ia harus mentaati ajaran Islam dan menjaga rahmat Allah tetap berada pada dirinya. Ia harus mampu memahami, meghayati dan mengamalkan ajarannya yang didorong oleh iman sesuai dengan akidah Islamiah. Untuk tujuan itulah, perempuan harus dididik melaui proses pendidikan Islam. Berdasarkan pandangan diatas, yaitu pentingnya

\footnotetext{
${ }^{9}$ Abdulloh Ipi dan Safarina, Ilmu Pendidikan (Jakarta: Rajagrafindo, 2015), 219.

${ }^{10} \mathrm{Ibid}, 340$.

${ }^{11}$ Achmadi, Ideologi Pendidikan Islam (Jakarta: Pustaka Setia, 2011 ), 31.

${ }^{12}$ Ibid, 206.
} 
pendidikan Islam bagi perempuan melalui sistem pendidikan yang dapat memberikan kemampuan agar memimpin kehidupannya sesuai dengan citacita Islam telah menjiwai dan mewarnai corak kepribadiannya. ${ }^{13}$ Maka penulis tertarik mengadakan penelitian yang berjudul "Nilai-nilai Pendidikan Islam yang Terkandung dalam al-Qur'an Surat Ali Imran Ayat 37’.

\section{B. Pembahasan}

1. Pengertian Nilai Pendidikan Islam

Nilai berasal dari bahasa latin value yang artinya berguna, mampu akan, berdaya, berlaku sehingga nilai diartikan sebagai sesuatu yang dipandang baik, bermanfaat dan paling benar menurut keyakinan seseorang atau sekelompok orang. Nilai adalah kualitas suatu hal yang menjadikan hal itu disukai, diinginkan, dikejar, dihargai, berguna dan dapat membuat orang yang menghayatinya menjadi bermartabat. ${ }^{14}$

Menurut Steeman sebagaimana dikutip oleh Sutarjo Adisusilo J.R dalam bukunya Pembelajaran Nilai Karakter nilai adalah sesuatu yang memberikan makna pada hidup, yang memberikan acuan, titik tolak dan tujuan hidup atau sesuatu yang dijunjung tinggi, yang dapat mewarnai dan menjiwai tindakan seseorang yang lebih dari sekedar keyakinan, selalu menyangkut pola pikir dan tindakan, sehingga ada hubungan erat antara nilai dan etika. ${ }^{15}$

Nilai adalah norma yang meletakkan perbuatan, cara bertingkah laku, dan tujuan pekerjaan diatas tahap yang dapat diterima atau tidak dapat diterima, yang diinginksn atau tidak diinginkan, atau yang dapat dianggap baik atau dianggap buruk. ${ }^{16}$ Nilai adalah kapasitas manusia yang dapat diwujudkan dalam bentuk gagasan atau konsep, kondisi psikologis atau tindakan yang berharga (nilai subyek), serta berharganya sebuah gagasan

${ }^{13}$ Nur Uhbiyati, Ilmu Pendidikan Islam ( IPI) (Bandung: Pustaka Setia, 1999), 12,13.

${ }^{14}$ Sutarjo Adisusilo, J.R, Pembelajaran Nilai Karakter (Jakarta: Rajagrafindo Persada, 2012), 56.

${ }^{15} \mathrm{Ibid}, 56$.

${ }^{16}$ Hasan Langgulung, Peralihan Paradigma dalam Pendidikan Islam dan Sains Sosial (Jakarta:Gaya Media Pratama, 2002 ), 91. 
atau konsep, kondisi psikologis atau tindakan (nilai obyek) berdasarkan standar agama, filsafat (etika atau estetika) serta norma masyarakat (rujukan nilai) yang diyakini oleh individu sehingga menjadi dasar menimbang, bersikap dan berperilaku dalam kehidupan pribadi maupun masyarakat (value system). ${ }^{17}$

Nilai akan selalu berhubungan dengan kebaikan, kebajikan dan keluhuran budi serta akan menjadi sesuatu yang dihargai dan dijunjung tinggi serta dikejar oleh seseorang sehingga ia merasakan ada sesuatu kepuasan, dan ia merasa menjadi manusia yang sebenarnya. Menurut Linda dan Richard Eyre sebagaimana dikutip oleh Sutarjo Adisusilo J.R dalam bukunya yang berjudul Pembelajaran Nilai Karakter menulis:

"Yang dimaksudkan dengan nilai adalah standar-standar perbuatan dan sikap yang menentukan siapa kita, bagaimana kita hidup, dan bagaimna kita memperlakukan orang lain. Tentu saja, nilai-nilai yang baik yang menjadikan orang lebih baik, hidup lebih baik, dan memperlakukan orang lain secara lebih baik. sedangkan yang dimaksudkan dengan moralitas adaah perilaku yang diyakini banyak orang sebgai benar dan sudah terbukti tidak menyusahkan orang lain, bahkan sebaliknya." 18

Maka nilai pendidikan Islam pada hakikatnya adalah kumpulan dari prinsip-prinsip hidup, ajaran-ajaran tentang bagaimana manusia seharusnya menjalankan kehidupannya di dunia ini, yang satu prinsip dengan yang lainnya saling terkait membentuk satu kesatuan yang utuh tidak dapat dipisah-pisahkan. Jadi nilai-nilai pendidikan Islam adalah sifat-sifat atau hal-hal yang melekat pada pendidikan Islam yang digunakan sebagai dasar manusia untuk mencapai tujuan hidup manusia yaitu mengabdi pada Allah SWT. Nilai-nilai tersebut perlu ditanamkan pada anak sejak kecil, karena pada waktu masih kecil adalah masa yang tepat untuk menanamkan kebiasaan yang baik padanya.

${ }^{17}$ Shapiah, Mu'adalah Jurnal Gender dan Anak (Banjarmasin: Pusat Studi Gender LP2M, 2015), 5.

${ }^{18}$ Sutarjo Adisusilo, J.R, Pembelajaran Nilai Karakter (Jakarta: Rajagrafindo Persada, 2012), 56. 
2. Sumber Nilai Pendidikan Islam

Menurut Zayadi yang dikutip oleh Abdul Majid dan Dian Andayani dalam bukunya Pendidikan Karakter Perspektif Islam mengemukakan sumber nilai yang berlaku dalam pranata kehidupan manusia dapat digolongkan menjadi dua macam, yaitu:

a. Nilai Ilahiyah.

Nilai ilahiyah yaitu nilai yang dititahkan Allah SWT. melalui para Rasul-Nya yang diabadikan pada wahyu. Inti nilai ini adalah iman dan takwa. Nilai ini tidak mengalami perubahan, karena mengandung kemutlakan bagi kehidupan manusia selaku pribadi dan selaku anggota masyarakat, tidak berubah karena mengikuti hawa nafsu. ${ }^{19}$ Dalam bahasa al-Qur'an, dimensi hidup ketuhanan ini juga disebut jiwa rabbaniyah. Nilai-nilai keagamaan pribadi yang amat penting yang harus ditanamkan kepada setiap anak didik. Kegiatan menanamkan nilai-nilai akan menjadi inti kegiatan pendidikan. ${ }^{20} \mathrm{Di}$ antara nilai-nilai yang sangat mendasar yaitu:

1). Iman

yaitu sikap batin yang penuh kepercayaan kepada Allah. jadi tidak cukup hanya percaya adanya Allah, melainkan harus meningkat menjadi sikap mempercayai kepada adanya Tuhan dan menaruh kepercayaan kepada-Nya.

2). Islam

Yaitu sebagai kelanjutan iman, maka sikap pasrah kepada-Nya, dengan meyakini bahwa apapun yang datang dari Tuhan tentu mengandung hikmah kebaikan, yang tidak mungkin diketahui seluruh wujudnya oleh kita yang dhoif. Sikap taat tidak absah (dan tidak dietrima oleh Tuhan) kecuali jika berupa pasrah (Islam) kepada-Nya.

\footnotetext{
${ }^{19}$ BukhariUmar59.blogspot.com. diakses 20 Agustus 2017.

${ }^{20}$ Abdul Majid dan Dian Andayani, Pendidikan Karakter Perspektif Islam (Bandung: Remaja Rosdakarya, 2012), 93, 94.
} 
3). Ihsan

Yaitu kesadaran sedalam-dalamnya bahwa Allah senantiasa hadir atau ada bersama hamba-Nya di manapun berada. Berkaitan ini Allah selalu mengawasi hamba-Nya, maka hendaknya harus berbuat, berlaku dan bertindak menjalankan sesuatu dengan sebaik mungkin dan penuh rasa tanggung jawab, tidak setengah-setengah dan tidak dengan menjauhi atau menjaga diri dari sesuatu yang tidak diridhoiNya.

4). Taqwa

Yaitu sikap yang sadar penuh bahwa Allah selalu mengawasi, maka hendaknya selalu berusaha berbuat sesuatu hanya yang diridhoi Allah, dengan menjauhi atau menjaga diri dari sesuatu yang tidak diridhoi-Nya.

5). Ikhlas

Yaitu sikap murni dalam tingkah laku dan perbuatan, sematamata demi memperoleh ridha atau perkenan Allah, dan bebas dari pamrih lahir dan batin, tertutup maupun terbuka. Dengan sikap yang ikhlas orang akan mampu mencapai tingkat tertinggi nilai karya batinnya dan karya lahirnya, baik pribadi maupun sosial.

6). Tawakkal

Yaitu sikap senantiasa bersandar kepada Allah, dengan penuh harapan kepadanya dan keyakinan bahwa Dia akan menolong dalam mencari dan menemukan jalan yang terbaik, karena mempercayai atau menaruh kepercayaan kepada Allah maka tawakkal adalah suatu kemestian.

7). Syukur

Yaitu sikap penuh rasa terima kasih dan penghargaan, dalam hal ini atas segala nikmat dan karunia yang tidak terbilang banyaknya, yang dianugerahkan Allah kepada hamba-Nya. Sikap bersyukur sebenarnya sikap optimis kepada Allah, karena itu sikap bersyukur kepada diri sendiri. 
8). Sabar

Yaitu sikap tabah menghadapi segala kepahitan hidup, besar dan kecil, lahir dan batin, fisiologis maupun psikologis karena keyakinan yang tidak tergoyahkan bahwa semua berasal dari Allah dan akan kembali kepada Allah. jadi sabar adalah sikap batin yang tumbuh karena kesadaran akan asal dan tujuan hidup yaitu Allah ${ }^{21}$

b. Nilai Insaniyah

Nilai insaniyah yaitu nilai yang tumbuh atas kesepakatan manusia serta hidup dan berkembang dari peradaban manusia. Nilai ini bersifat dinamis, yang keberlakuannya relatif dan dibatasi oleh ruang dan waktu. ${ }^{22}$ Pendidikan tidak hanya dipahami secara terbatas hanya kepada pengajaran. Karena itu keberhasilan pendidikan bagi anak-anak tidak cukup diukur hanya dari segi seberapa jauh anak itu menguasai hal-hal yang bersifat kognitif atau pengetahuan tentang suatu masalah semata.

Justru yang lebih penting bagi umat Islam, berdasarkan ajaran kitab suci dan sunnah sendiri, ialah seberapa jauh tertanam nilai-nilai kemanusiaan yang mewujud nyata dalam tingkah laku dan budi pekertinya sehari-hari akan melahirkan budi luhur atau al-akhlaq alkarimah. Dalam menjalankan pendidikan, menanamkan nilai-nilai akhlaq kepada anak didik diantaranya:

1). Sillat al-rahmi

Yaitu pertalian rasa cinta kasih antara sesama manusia, khususnya antara saudara, kerabat, handai taulan, tetangga, dan seterusnya. Sifat utama Tuhan adalah kasih (rahim, rahmah) sebagai satu-satunya sifat ilahi yang diwajibkan sendiri atas Diri-Nya. Maka manusia harus cinta kepada sesamanya, agar Allah cinta kepadaNya, irhamu man fi al-ardl, yarhamukum man fi al-sama, kasihilah makhluk yang ada dibumi maka (Dia) yang ada dilangit akan kasih kepadamu.

\footnotetext{
${ }^{21}$ Abdul Majid dan Dian Andayani, Pendidikan Karakter Perspektif Islam (Bandung: Remaja Rosdakarya, 2012), 93, 94.

${ }^{22}$ BukhariUmar59. blogspot. com. diakses 20 Agustus 2017.
} 


\section{2). Al-Ukhuwah}

Yaitu semangat persaudaraan, terlebih kepada sesama orang yang beriman (ukhuwah islamiyah) seperti disebutkan dalam alQur'an surat Al-Hujurat(49): 10-12, yang intinya ialah hendaknya kita tidak merendahkan golongan yang lain, jangan-jangan mereka itu lebih baik dari pada kita sendiri, tidak saling menghina, saling megejek, banyak berprasangka, suka mencari-cari kesalahan orang lain, dan suka mengumpat (membicarakan keburukan seseorang yang tidak ada didepan kita).

3). Al-Musawah

Yaitu pandangan bahwa semua manusia, tanpa memandang jenis kelamin, kebangsaan ataupun kesukuannya, dan lan-lain adalah sama dalam harkat dan martabat. Tinggi rendah manusia hanya ada dalam pandangan Allah yang tahu kadar ketaqwaaannya.

4). Al-'Adalah

Yaitu wawasan yang seimbang atau balance dalam memandang, menilai atau menyikapi sesuatu atau seseorang, dan seterusnya. Jadi, tidak secara apriori menunukkan sikap positif atau negatif. Sikap kepada sesuatu atau seseorang dilakukan hanya setelah mempertimbangkan segala segi tentang sesuatu atau seseoran tersebut secara jujur dan seimbang, dengan penuh i'tikad baik dan bebas dari prasangka. Sikap ini juga yang disebut tengah (wasth) dan al-Qur'an menyebutkan bahwa kaum beriman dirancang oleh Allah untuk menjadi golongan tengah (ummat wasathan) agar dapat menjadi saksi untuk sekalian umat manusia, sebagai kekuatan penengah (wasith).

\section{5). Husnu al-dzan,}

Yaitu berbaik sangka kepada sesama manusia, dan berdasarkan ajaran agama bahwa manusia itu pada asal dan hakikat aslinya adalah baik, karena diciptakan Allah dan dilahirkan atas fitrah kejadian asal yang suci. Sehingga manusia itu pun pada hakikat aslinya adalah 
makhluk yang berkecenderungan kepada kebenaran dan kebaikan (hanif).

6). Al-Tawadlu’

Yaitu sikap rendah hati, sebuah sikap yang tumbuh karena keinsafan bahwa segala kemuliaan hanya milik Allah, maka tidak sepantasnya manusia mengklaim kemuliaan itu kecuali dengan pikiran yang baik dan perbuatan yang baik, yang itu pun hanya Allah yang akan menilainya (Q.S: Fathir: 10). Lagi pula, kita harus rendah hati karena ingatlah diatas setiap orang berilmu adalah Dia Yang Maha berilmu (Q.S: Yusuf12: 76). Apalagi kepada sesama orang yang beriman, sikap rendah hati itu adalah suatu kemestian. Hanya kepada mereka yang jelas-jelas menentang kebenaran kita diperbolehkan untuk bersikap tinggi hati (QS: Al-Maidah 5: 54 dan QS Al-Fath 48: 29).

7). Al-wafa

Yaitu tepat janji. Salah satu sifat orang yang benar-benar beriman ialah sikap selalu menepati janji bila membuat perjanjian (QS: Al-Baqarah 2: 177). Dalam masyarakat dengan pola hubungan yang lebih kompleks dan luas, sikap tepat janji lebih-lebih lagi merupakan unsr budi luhur yang amat diperlukan dan terpuji.

8). Insyirah

Yaitu sikap lapangan dada, yaitu sikap penuh kesediaan menghargai orang lain dengan pendapat-pendapat dan pandanganpandangannya. Seperti dituturkan dalam al-Qur'an mengenai sikap Nabi sendiri disertai pujian kepada beliau (QS: Ali Imran 3: 159). Sikap terbuka dan toleran serta kesediaan bermusyawarah secara demokratis terkait erat sekali dengan lapang dada ini.

9). Al-Amanah

Yaitu dapat dipercaya, sebagai konsekuensi iman ialah amanah atau penampilan diri yang dapat dipercaya. Amanah sebagai budi luhur dalah lawan dari khiyanah yang amat tercela. 
10). Iffah atau ta' 'affuf

Yaitu sikap penuh harga diri, namun tidak sombong, jadi tetap rendah hati, dan tidak mudah menunjukkan sikap memelas atau iba dengan maksud mengundang belas kasihan orang lain dan mengharapkan pertolongannya (QS: Al-Baqarah 2: 273).

11). Qawamiyah,

Yaitu sikap tidak boros (israf) dan tidak perlu kikir (qatr) dalam menggunakan harta, melainkan sedang (qawam) antara keduanya (QS Al-Furqan 25 : 67). Apalagi al-Qur'an menggambarkan bahwa orang yang boros adalah teman syetan yang menentang Tuhan-Nya (QS: Al-Isra 17: 26).

12). Al-Munfiqun,

Yaitu sikap orang beriman yang memiliki kesediaan yang besar untuk menolong sesama manusia, terutama pada yang kurang beruntung (fakir miskin dan terbelenggu oleh perbudakan dan kesulitan hidup lainnya (raqabah) dengan mendermakan sebagian dari harta benda yang dikaruniakan dan diamanatkan Tuhan kepada mereka. Sebab manusia tidak akan memperoleh kebaikan sebelum mendermakan sebagian harta benda yang dicintainya itu (QS: AliImran 3: 17 dan 93). ${ }^{23}$

Jadi dari pengertian-pengertian diatas maka dapat disimpulkan bahwa penanaman nilai-nilai religius berupa nilai Ilahiyah dan nilai Insaniyah bertujuan untuk memperkuat hablum munaallah (hubungan mausia dengan Allah) dan hablum minannas (hubungan manusia dengan sesama).

\section{Analisis}

1. Analisa Potongan Ayat 37 Surat Ali Imran, yang berbunyi:

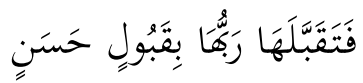

${ }^{23}$ Abdul Majid dan Dian Andayani, Pendidikan Karakter Perspektif Islam, 93-98. 
Artinya: Maka Tuhannya menerimanya (sebagai nazar) dengan penerimaan yang baik.

Dari potongan ayat diatas mengandung nilai Ilahiyah dan Insaniyah:

a. Nilai Ilahiyah dari ayat tersebut antara lain: Iman yaitu sikap batin yang penuh kepercayaan kepada Allah. ${ }^{24}$ Dalam tafsir Ibnu Katsir juga menerangkan tentang Allah memberitau bahwa Allah telah menerima Maryam sebagai nadzar Hannah dengan penerimaan yang baik. $^{25}$ Hal ini menunjukan bahwa ibunya Maryam memiliki keimanan yakni sikap batin yang penuh kepercayaan kepada Allah dengan menadzarkan anaknya untuk agama Allah.

Islam yaitu sebagai kelanjutan iman, maka sikap pasrah kepada-Nya, dengan meyakini bahwa apapun yang datang dari Tuhan tentu mengandung hikmah kebaikan, yang tidak mungkin diketahui seluruh wujudnya oleh kita yang dhoif. ${ }^{26}$ Maka sikap Hanah yang pasrah kepada Allah, dengan meyakini bahwa apapun yang datang dari Tuhan tentu mengandung hikmah kebaikan, yang tidak mungkin diketahui seluruh wujudnya oleh kita yang dhoif. Hikmah kebaikan berupa ketika Allah mempercayakan pengasuhan kepada Nabi Zakaria Maryam memperoleh bentuk tubuh yang bagus dan paras yang manis. Maryam diajarkan ilmu dan segala kebajikan.

Ikhlas yaitu sikap murni dalam tingkah laku dan perbuatan, semata-mata demi memperoleh ridha atau perkenan Allah, dan bebas dari pamrih lahir dan batin, tertutup maupun terbuka. ${ }^{27}$ Dalam tafsir Ibnu Katsir menunjukan bahwa sikap Hannah dengan ikhlas melepaskan putranya yakni Maryam untuk diasuh oleh Nabi Zakaria dan dalam rangka menepati janjinya kepada Allah.

24 Abdul Majid dan Dian Andayani, Pendidikan Karakter Perspektif Islam (Bandung: Remaja Rosdakarya, 2012), 93.

${ }^{25}$ Penterj. Salim Bahreisy dan Said Bahreisy, Tafsir Ibnu Katsier Jilid 2 (Surabaya: Bina Ilmu, 2005), 57

${ }^{26}$ Andayani, Pendidikan Karakter Perspektif Islam, 93.

${ }^{27}$ Abdul Majid dan Dian Andayani, Pendidikan Karakter Perspektif Islam (Bandung: Remaja Rosdakarya, 2012), 93-98. 
b. Nilai Insaniyah dari potongan ayat tersebut adalah al-wafa' yaitu tepat janji. Salah satu sifat orang yang benar-benar beriman ialah sikap selalu menepati janji bila membuat perjanjian. ${ }^{28}$ Di dalam tafsir Ibnu Katsir menunjukan bahwa sikap tepat janji Hanah yang pernah bernadzar putranya untuk agama Allah dan dalam hal ini merupakan salah satu sifat Hanah yang benar-benar beriman kepada Allah dengan menepati janjinya kepada Allah SWT.

2. Analisa Potongan Ayat 37 Surat Ali Imran, yang berbunyi:

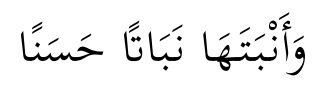

Artinya: Dan mendidiknya dengan pendidikan yang baik.

Dari potongan ayat di atas mengandung nilai-nilai pendidikan yakni: Nilai Ilahiyah: Tawakal yaitu sikap senantiasa bersandar kepada Allah dengan penuh harapan kepadanya dan keyakinan. ${ }^{29}$ Di dalam kitab tafsir Ibnu Katsir juga dijelaskan bahwa Allah memberitahu telah menerima Maryam sebagai nadzar ibunya dengan penerimaan yang baik ${ }^{30}$ Hal ini menunjukan bahwa Hanah memiliki sifat tawakal kepada Allah dengan bersandar kepada Allah dengan penuh harapan kepadanya dan keyakinan menepati janjinya kepada Allah sehingga Maryam dijadikan Allah diajari ilmu dan segala kebaikan untuk dirinya.

Sabar yaitu sikap tabah menghadapi segala kepahitan hidup, besar dan kecil, lahir dan batin karena keyakinan yang tidak tergoyahkan bahwa semua berasal dari Allah dan akan kembali kepada Allah SWT. ${ }^{31}$ Menurut peneliti sesuai tafsir Ibnu Katsir Nabi Zakariya yang dengan sabar mendidik Maryam dengan pendidikan jasmani dan ruhani. Pendidikan Jasmani ini ditunjukan dengan Maryam memperoleh badan

${ }^{28}$ Ibid, 93.

29 Abdul Majid dan Dian Andayani, Pendidikan Karakter Perspektif Islam (Bandung: Remaja Rosdakarya, 2012),

30 Penterj. Salim Bahreisy dan Said Bahreisy, Tafsir Ibnu Katsier Jilid 2 (Surabaya: Bina Ilmu, 2005), 57, 58, 59 .

${ }^{31}$ Andayani, Pendidikan Karakter Perspektif Islam, 93. 
yang bagus dan paras yang manis. Pendidikan ruhani Maryam yakni ketika berada di mihram selalu tekun beribadah kepada Allah.

3. Analisa Potongan Ayat 37 Surat Ali Imran, yang berbunyi:

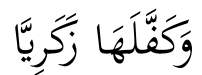

Artinya: Dan Allah menjadikan Zakariya pemeliharanya

Dari potongan ayat tersebut diatas mengandung nilai:

Nilai Insaniyah: Al-Ukhuwah yaitu semangat persaudaraan terlebih kepada sesama orang yang beriman. ${ }^{32}$ Dalam kitab Ibnu Katsir disini Allah pemeliharaannya ditugaskan Zakaria suami bibinya, karena ia seorang anak yatim atau menurut sementara ahli tafsir karena pada waktu Bani Israil sedang mengalami tahun kering Allah menyerahkan pemeliharaannya kepada Zakaria selain itu ia adalah suami bibinya juga untuk memperoleh daripadanya pendidikan yang baik pengetahuan yang berguna dan amal yang sholeh. ${ }^{33}$ Menurut peneliti Nabi Zakaria menunjukan sikap semangat persaudaraannya kepada Maryam yang masih saudaranya dengan memeliharanya dan atas izin Allah memberikan pendidikan kepadanya

Al-amanah yaitu dapat dipercaya, sebagai konsekuensi iman ialah amanah atau penampilan diri yang dapat dipercaya. ${ }^{34}$ Menurut peneliti ayat ini mengandung nilai al-amanah sebab Allah secara langsung menunjuk memilih Nabi Zakaria sebagai pemelihara Maryam yang dapat menjaga memelihara Maryam dengan baik.

Al-Munfiqun yaitu sikap orang beriman yang memiliki kesediaan yang besar untuk menolong sesama manusia, terutama pada yang kurang

32 Abdul Majid dan Dian Andayani, Pendidikan Karakter Perspektif Islam (Bandung: Remaja Rosdakarya, 2012), 98

${ }^{33}$ Penterj. Salim Bahreisy dan Said Bahreisy, Tafsir Ibnu Katsier Jilid 2 (Surabaya: Bina Ilmu, 2005), 57, 58.

34 Abdul Majid dan Dian Andayani, Pendidikan Karakter Perspektif Islam (Bandung: Remaja Rosdakarya, 2012), 93-98. 
beruntung. ${ }^{35}$ Menurut peneliti ayat ini menunjukan bahwa Nabi Zakaria adalah mempunyai sikap orang beriman yang memiliki kesediaan yang besar untuk menolong sesama manusia yang dalam hal ini adalah menolong mengasuh Maryam.

4. Analisa Potongan Ayat 37 Surat Ali Imran, yang berbunyi:

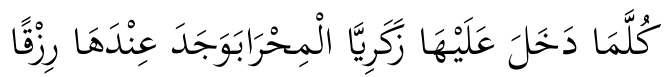

Artinya: Setiap Zakariya masuk untuk menemui Maryam di mihrab, ia dapati makanan di sisinya.

Dari potongan ayat tersebut diatas mengandung nilai:

Nilai Ilahiyah: Iman, yaitu sikap batin yang penuh kepercayaan kepada Allah. ${ }^{36}$ Dalam potongan ayat diatas menunjukan bahwa sikap batin Maryam yang penuh kepercayaan kepada Allah sikapnya yang tabah dan tekun ditempat ibadah yakni selalu mendekatkan diri kepada Allah SWT dan juga sikap yakin Nabi Zakaria ketika melihat buahbuahan langka disisi Maryam.

Islam, sebagai kelanjutan iman, maka sikap pasrah kepada -Nya, dengan meyakini bahwa apapun yang datang dari Tuhan tentu mengandung hikmah kebaikan, yang tidak mungkin diketahui seluruh wujudnya oleh kita yang di dhoif. ${ }^{37}$ Dalam kandungan ayat diatas menurut penulis sesuai tafsir Ibnu Katsir menunjukan bahwa sikap Maryam yang pasrah kepada Allah, dengan meyakini bahwa apapun yang datang dari Tuhan tentu mengandung hikmah kebaikan, ketika tiap kali Nabi Zakaria datang dengan melihat disisinya makanan, berupa buahbuahan musim panas diwaktu musim dingin atau buah-buahan musim dingin di waktu musim panas yang pendapat Mujahid, bahwa yang dimaksud dengan rezeki disini ialah lembaran-lembaran ilmu.

\footnotetext{
${ }^{35}$ Ibid, 93.

${ }^{36}$ Ibid, 98.

37 Abdul Majid dan Dian Andayani, Pendidikan Karakter Perspektif Islam (Bandung: Remaja Rosdakarya, 2012), 93-98.
} 
Taqwa, yaitu sikap yang sadar penuh bahwa Allah selalu mengawasi, maka hendaknya selalu berusaha berbuat sesuatu hanya yang di ridhoi Allah, dengan menjauhi atau menjaga diri dari sesuatu yang tidak diridhoi-Nya. Menurut peneliti dalam ayat ini menunjukan ketaqwaan Maryam dengan berada disebuah mihrab yang selalu menjaga diri mendekatkan diri kepada Allah SWT.

Tawakkal, yaitu sikap senantiasa bersandar kepada Allah, dengan penuh harapan kepada-Nya dan keyakinan. Menurut peneliti Maryam mempunyai sifat tawakal ketika berada di sebuah mihrab Maryam selalu mendekatkan diri kepada Allah.

Sabar, yaitu sikap tabah menghadapi segala kepahitan hidup besar dan kecil, dan batin karena keyakinan yang tidak tergoyahkan bahwa sesungguhnya semuanya berasal dari Allah dan akan kembali kepada Allah. ${ }^{38}$ Menurut peneliti dalam potongan ayat di atas menunjukan bahwa Maryam memiliki sifat sabar yakni sabar ketika berada didalam sebuah mihrab dengan tabah dan tekun ditempat ibadahnya.

5. Analisa Potongan Ayat 37 Surat Ali Imran, yang berbunyi:

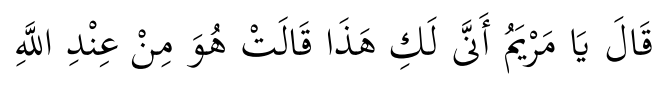

Artinya: Zakariya berkata: "Hai Maryam dari mana kamu memperoleh (makanan) ini? Maryam menjawab: "Makanan itu dari sisi Allah"."

Dari potongan ayat tersebut diatas mengandung nilai Ilahiyah: Iman yaitu sikap batin yang penuh kepercayaan kepada Allah SWT. Dalam kandungan potongan ayat tersebut dapat peneliti analisa menunjukan bahwa Maryam mempunyai sikap batin yang penuh kepercayaan kepada Allah SWT dengan meyakini bahwa makanan yang diperolehnya itu semata-mata dari Allah SWT. Islam, sebagai kelanjutan iman,maka sikap pasrah kepada-Nya, dengan meyakini bahwa apapun yang datang dari Tuhan tentu mengandung hikmah kebaikan. Dapat peneliti analisa bahwa

${ }^{38} \mathrm{Ibid}, 98$. 
sikap pasrah Maryam terhadap rezeki yang diterimanya merupakan mengandung hikmah kebaikan yakni ada yang menafsirkan bahwa makanan itu adalah lembaran-lembaran ilmu.

6. Analisa Potongan Ayat 37 Surat Ali Imran, yang berbunyi:

$$
\text { إِنَّ اللَّ يَرْزُقُقُ مَنْ يَشَاءُ بِغَيْرِ حِسَاب (TV) }
$$

Artimya: Sesungguhnya Allah memberi rezeki kepada siapa yang dikehendaki-Nya tanpa hisab.

Potongan ayat tersebut mengandung Nilai Ilahiyah: Syukur yaitu sikap penuh rasa terima kasih dan penghargaan, dalam hal ini atas segala nikmat dan karunia yang tidak terbilang banyaknya, yang dianugerahkan Allah kepada kita. ${ }^{39}$ Dalam hal ini sesuai dengan sikap Maryam yang berkata jujur telah diberi karunia yang tidak terbilang banyaknya yang dianugerahkan oleh Allah SWT. berupa hidangan dari sisi-Nya dengan mengucapkan ketika Zakaria datang menjenguknya dimihrabnya kalau rezekinya datangnya dari Allah dengan tanpa hisab. Maka menurut peneliti Maryam memiliki sikap syukur kepada Allah.

Iman yaitu sikap batin yang penuh kepercayaan kepada Allah. ${ }^{40}$ Dengan demikian dalam hal ini sesuai dengan sikap batin Maryam yang penuh kepercayaan kepada Allah bahwa rezeki itu datangnya dari Allah dengan tanpa hisab.

Tawakal yaitu sikap senantiasa bersandar kepada Allah, dengan penuh harapan kepadanya dan keyakinan. ${ }^{41}$ Dengan demikian hal itu sesuai dengan sikap Maryam yang senantiasa bersandar kepada Allah dengan penuh harapan kepada-Nya berserah diri kepadaNya terhadap kehendak Allah SWT yaitu menerima rezeki dari-Nya.

Nilai Insaniyah: Al-Tawadhu' yaitu sikap rendah hati, sebuah sikap yang tumbuh karena keinsafan bahwa segala kemuliaan hanya milik

\footnotetext{
39 Abdul Majid dan Dian Andayani, Pendidikan Karakter Perspektif Islam (Bandung: Remaja Rosdakarya, 2012), 98.

${ }^{40}$ Ibid, 93.

${ }^{41}$ Ibid, 98.
} 
Allah, maka tidak sepantasnya manusia mengklaim kemuliaan itu kecuali dengan pikiran yang baik dan perbuatan yang baik, yang itu pun hanya Allah yang akan menilainya. ${ }^{42}$ Hal ini sesuai dengan sikap rendah hati Maryam yang memuji Allah bahwa segala kemuliaan hanya milik Allah dengan mengatakan bahwa sesungguhnya hidangan yang didatangkan itu adalah milik Allah dan dari Allah. maka dalam hal ini ayat ini mengandung nilai al-tawadhu'.

Husnudhan, yaitu berbaik sangka kepada sesama manusia, dan berdasarkan ajaran agama bahwa manusia itu pada asal dan hakikat aslinya adalah baik, karena diciptakan Allah dan dilahirkan atas fitrah kejadian asal yang suci. ${ }^{43}$ Sikap Maryam yang berbaik sangka kepada Allah bahwa hidangan yang datang padanya adalah semata-mata dari Allah.

Jadi dari paparan data yang telah peneliti analisa dapat disimpulkan bahwa dalam Al-Qur'an Surat Ali Imran ayat 37 mengandung dua nilai pendidikan Islam yaitu nilai Ilahiyah dan Insaniyah. Nilai Ilahiyah antara lain iman, Islam, taqwa, ikhlas, tawakal, syukur, dan sabar. Sedangkan nilai Insaniyah diantaranya al-ukhuwah, husnudzan, tawadhu', al-wafa, al-amanah, dan al-munfiqun.

\section{Penutup}

Nilai-nilai pendidikan Islam yang terkandung dalam al-Qur'an Surat Ali Imran Ayat 37 ada dua yaitu nilai Ilahiyah dan Insaniyah. Nilai Ilahiyah: 1). Iman: Keyakinan ibunya Maryam menadzarkan putranya untuk agama Allah, keyakinan Maryam selalu mendekatkan diri kepada Allah ketika berada dimihrab, keyakinan Maryam terhadap rezeki yang berupa hidangan yang diperolehnya semata-mata dari Allah, sikap yakin Nabi Zakaria ketika melihat buah-buahan langka disisi Maryam 2). Islam: sikap ibunya Maryam (Hana) yang pasrah kepada Allah dengan mempercayakan pengasuhan

${ }^{42}$ Ibid, 98.

${ }^{43}$ Ibid, 98. 
Maryam kepada Nabi Zakaria sehingga memperoleh kebaikan, sikap pasrah Maryam atas rezeki yang diterima dari Allah SWT, 3). Taqwa: sikap Maryam selalu menjaga dan mendekatkan diri kepada Allah ketika di mihrab, 4). Ikhlas: keikhlasan Nabi Zakaria untuk mengasuh Maryam untuk menepati janji Hana. 5). Tawakal: sikap Maryam berserah diri atas pemberian rezeki dari Allah SWT, sikap Maryam yang yang menepati janji menadzarkan putranya untuk agama Allah. 6). Syukur: Maryam bersyukur atas nikmat karunia hidangan dari Allah. 7). Sabar: kesabaran Maryam ditempatkan didalam mihrab dan tekun beribadah.

Nilai Insaniyah: 1). Al-ukhuwah: semangat persaudaraan Nabi Zakaria dengan memelihara memberikan pendidikan kepada Maryam. 3). Tawadhu': rendah hati Maryam memuji Allah atas datangnya hidangan dari Allah SWT. 4). Al-wafa: Maryam menunaikan nadzarkan kepada Allah. 5). Husnudzan: Maryam berbaik sangka pada Allah yang telah diberi nikmat hidangan dariNya. 6). Al-amanah: Maryam yang selalu menjaga diri dengan baik di mihrab. 7). Al-munfiqun: Nabi Zakaria menolong Maryam dengan mengasuh dan mendidiknya.

\section{BIBLIOGRAPHY}

Abdul Majid dan Dian Andayani, Pendidikan Karakter Perspektif Islam. Bandung: Remaja Rosdakarya, 2012.

Abdulloh Ipi dan Safarina, Ilmu Pendidikan, Jakarta: Rajagrafindo.

Achmadi, Ideologi Pendidikan Islam, Jakarta: Pustaka Setia, 2011.

Adisusilo, Sutarjo, J.R, Pembelajaran Nilai Karakter. Jakarta: Rajagrafindo Persada, 2012.

Farikhah, Siti, Manajemen Lembaga Pendidikan. Yogyakarta: Aswaja Pressindo, 2011.

Langgulung, Hasan, Peralihan Paradigma dalam Pendidikan Islam dan Sains Sosial. Jakarta:Gaya Media Pratama, 2002.

Muslim, Bukhari, Hadis Tarbawi, Jakarta: Amzah, 2006. 
Mustofa, Ali, Pendidikan Keagamaan Untuk Membentuk Kerukunan Antar Umat Beragama Di Medowo Kandangan Kediri, Nazhruna: Jurnal Pendidikan Islam Vol. 3 No 1 2020. Hal. 17. ISSN: 2614-8013. DOI: https://doi.org/10.31538/nzh.v3i1.399

Indana, Nurul, Kepimpinan Kepala Sekolah dalam Pengembangan Pembelajaran PAI di SMP Islam Terpadu Misykat Al Anwar Kwaron Diwek Jombang. Jurnal Al-Idaroh Vol.3 No.2 September 2019.

Nata, Abuddin, Metodologi Studi Islam. Jakarta: RajaGrafindo Persada, 2012.

Salim Bahreisy dan Said Bahreisy (Penterj.) Tafsir Ibnu Katsier Jilid 2. Surabaya: Bina Ilmu, 2005.

Shapiah, Mu'adalah Jurnal Gender dan Anak. Banjarmasin: Pusat Studi Gender LP2M, 2015.

Suhartono, Suparlan, Filsafat Pendidikan, Yogyakarta: Ar-Ruzz, 2006.

Uhbiyati, Nur, Ilmu Pendidikan Islam ( IPI). Bandung: Pustaka Setia, 1999. 